\title{
CURRENT RESEARCH STRATEGIES FOR SUNFLOWER BROOMRAPE CONTROL IN SPAIN
}

\author{
Fernández-Martínez, J.M. ${ }^{{ }^{*}}$, Domínguez, J. $^{2}$, Pérez-Vich, B. ${ }^{1}$ \\ and Velasco, L. ${ }^{1}$ \\ ${ }^{1}$ Institute for Sustainable Agriculture (CSIC) Alameda del Obispo s/n. \\ Apartado 4084. E-14080 Córdoba, Spain \\ ${ }^{2}$ CIFA "Alameda del Obispo", IFAPA-CICE, Junta de Andalucía, Córdoba, Spain
}

Received: July 15, 2009

Accepted: November 10, 2009

\begin{abstract}
SUMMARY
Sunflower broomrape (Orobanche cumana Wallr) continues to be one of the most important constraints in sunflower production in Spain. In the last ten years, genetic resistance has been the predominant control strategy against $O$. cumana. However, the introduction of new resistance genes has been frequently followed by the occurrence of new virulent races overcoming their resistance. In this report, a combined control strategy against $O$. cumana is discussed, including: a) the use of IMI sunflower cultivars to control winter and early spring weeds and sunflower broomrape; b) the combination of vertical and horizontal resistance mechanisms in the same genotype, supported by molecular markers in order to develop a more durable resistance; c) the study of the variability and racial composition of Spanish sunflower broomrape populations using classical and molecular approaches with the objective to learn about population dynamics in this parasitic weed. The combination of such strategies is expected to contribute to improved sunflower performance in areas infested by broomrape in the Mediterranean area.
\end{abstract}

Key words: broomrape control, Helianthus annuus, resistance mechanisms, IMI sunflower, QTL mapping

\section{INTRODUCTION}

Sunflower broomrape (Orobanche cumana Wallr.) is a weedy parasitic angiosperm that currently represents a serious constraint for sunflower production in Spain as well as in other countries of Southern Europe and the Black Sea region (Parker, 1994; Melero Vara et al., 2000). Broomrape attacks are frequently severe and yield losses can reach up to 50\% (Domínguez, 1996). Although the use of herbicides is being considered as a promising control measure, in recent years genetic resistance has been the most widespread method of $O$. cumana control. Breeding

* Corresponding author: Phone: +34 957 499204, Fax: +34 957 499252;

e-mail: cs9femaj@uco.es 
strategies for incorporating broomrape resistance into sunflower commercial hybrids have been nearly exclusively based on single race-specific dominant genes, which are considered by seed companies as an ideal source of resistance for singlecross hybrid breeding, as they only need to be incorporated into one of the parents (Fernández-Martínez et al., 2008). However, the extensive use of vertical resistance has probably contributed to the rapid evolution of $O$. cumana populations, leading to the appearance of new virulent races after the introduction of new resistant cultivars, which has required a continuous search for new resistance sources.

In Spain, a new race $\mathrm{F}$, capable of overcoming all the known resistance genes $\mathrm{Or}_{1}$ through $\mathrm{Or}_{5}$, which provide resistance to the races A through E described by Vrânceanu et al. (1980), was identified in 1995 (Alonso et al., 1996; Dominguez, 1999) and it spread rapidly. Resistance to this new race was found in germplasm of both cultivated and wild sunflowers (Sukno et al., 1999; Fernández-Martínez et al., 2000; Rodríguez-Ojeda et al., 2001), but a more virulent race G was identified soon after cultivars resistant to race $\mathrm{F}$ entered the market (Molinero-Ruiz and MeleroVara, 2005). Virulent races overcoming the resistance gene $\mathrm{Or}_{5}$ have also been identified in Romania (Pâcureanu et al., 2004), Russia (Goncharov et al., 2004), Israel (Eizenberg et al., 2004), Bulgaria (Shindrova, 2006) and Turkey (Kaya et al., 2004). In the last country, the new races seem to be more virulent than those present in other countries.

Given the situation described above, integration of several control measures is becoming crucial to develop long-term strategies for sunflower broomrape management. Particular attention is being given to herbicide control using imidazolinone (IMI) resistant cultivars, new breeding strategies to make resistance more durable, and understanding the mechanisms underlying the rapid evolution of the parasite by studying the genetic structure and variability of $O$. cumana populations as well as their evolution.

\section{Use of herbicide-tolerant IMI cultivars}

A wild sunflower population of Helianthus annuus highly tolerant to the herbicide imazethapyr was found in a soybean field in Kansas, USA (Al-Khatib et al., 1998). Seed specimens of this material were used by the Agricultural Research Service at Fargo ND to transfer herbicide tolerance to cultivated sunflower. This prospect was very exciting because of the extensive list of weeds controlled in postemergence by imazethapyr herbicide and other herbicides of the imidazolinone chemical family (IMI), including annual and perennial broadleaf weeds, grasses and volunteer cereals. This option greatly increases the farmer's choices for weed control, restricted so far to the more expensive, less effective pre-emergent options. Moreover, IMI herbicides have proven to be highly efficient in controlling sunflower broomrape (Alonso et al., 1998), offering an excellent opportunity for the chemical control of the parasitic weed. Broomrape herbicide control is not race specific and 
may serve both to prevent the parasite from spreading to new areas as well as to control it in already infested areas.

Introgression of genes underlying the herbicide tolerance trait from the original wild population to cultivated sunflower was successful and genetic stocks and breeding lines with imidazolinone herbicide resistance have been developed and released (Al-Khatib and Miller, 2000; Miller and Al-Khatib, 2002) for the development of commercial resistant hybrids. Herbicide-tolerant (HT) sunflowers have gained a market share very quickly once the HT trait was incorporated into highperforming hybrids. In some countries such as Turkey, Bulgaria and Romania, the sunflower area planted with HT hybrids exceeded $25 \%$ in only three tor four years after their introduction (Alonso, 2008). Current prospects indicate that this tendency is going to continue, with an increasing number of performing HT hybrids being available.

The situation with HT hybrids in Spain was very different. Because of low average yields $(<1 \mathrm{t})$, mainly determined by water shortage during grain filling, farmers have been reluctant to accept the increased costs per hectare derived from the new herbicide treatments. Therefore, the HT sunflower represents only around $3 \%$ of the total planted area in the recent years (Alonso, 2008). However, this situation is changing due to the incidence of new races of broomrape and an increasing area of winter-planted sunflower that needs an effective postemergence herbicide treatment.

Recently, we have started an integrated research program including several strategies for increasing sunflower yield in Mediterranean type of cropping conditions, in which winter and spring weeds as well as sunflower broomrape are systematic problems. One of these strategies deals with evaluating different IMI resistant cultivars under early planting conditions in several locations in order to identify the cultivars well adapted to winter planting in different environmental conditions. Additional objectives of this program are to identify the optimal phenological stages and the most suitable techniques for herbicide application to control both weeds and broomrape, and to gather information on the influence of winter vs spring planting dates on broomrape incidence.

\section{Breeding strategies for more durable resistance}

Genetic resistance is the most effective and economical control measure against broomrape. However, since $O$. cumana is a highly variable parasite, the breakdown of resistance is a frequent phenomenon, and there is a continuous need of new resistance sources. In the early sunflower breeding work conducted in the former USSR and Romania, sources of resistance to Orobanche races were found within landraces of cultivated sunflower and they were also introgressed from wild species, mainly H. tuberosus (Pustovoit, 1966; Vrânceanu et al., 1980). Sources of resistance to the recent virulent races $\mathrm{E}$ and $\mathrm{F}$ have been scant in cultivated germplasm (Gulya et al., 1994; Domínguez et al., 1996; Fernández-Martínez et al., 
2000) although lines with resistance to races $\mathrm{E}$ and $\mathrm{F}$ have been developed, especially from material tracing back to old Russian cultivars (Fernández-Martínez et al., 2004). In contrast, a high level of resistance to races E, F and G has been found in the evaluation of wild Helianthus species, particularly perennials (Škorić, 1988; Christov et al., 1996; Ruso et al., 1996; Fernández-Martínez et al., 2000), revealing that wild Helianthus species constitute a major pool of genes for resistance to the new virulent races of broomrape.

In general, transferring broomrape resistance genes from old landraces and wild annual species into cultivated lines with good agronomic characteristics can be accomplished rather easily with a conventional crossing and backcrossing scheme. Conversely, transfer of resistance from perennial species is generally more difficult due to problems associated with early hybrid embryo abortion and sterility in the $\mathrm{F}_{1}$ and $\mathrm{BCF}_{1}$ generations. However, such problems can be overcome with the utilization of embryo rescue and chromosome doubling of the $F_{1}$. By following this approach, resistance to race $\mathrm{F}$ has been transferred from $H$. grosseserratus, $H$. maximiliani and H. divaricatus (Jan and Fernández-Martínez, 2002; Jan et al., 2002). Resistance to race $F$ has also been identified in accessions of cultivated germplasm (Fernández-Martínez et al., 2004; Pérez-Vich et al., 2006a).

Since a comprehensive review on inheritance of sunflower broomrape resistance has been recently published (Fernández-Martinez et al., 2008), here we shall discuss only the aspects related to new breeding strategies towards improving durability of genetic resistance. Most genetic studies conducted on the different resistance sources to races A through $\mathrm{E}$ concluded that a major dominant gene conferred resistance to the latest race and also to the previous ones (Vrânceanu et al., 1980; Ish-Shalom-Gordon et al., 1993; Sukno et al., 1999). For example, the Or $_{5}$ gene confers resistance to all the five races, A through E. This led seed companies to follow breeding strategies nearly exclusively based on the use of monogenic resistance mechanisms, rapidly overcome by the parasite. The occurrence of the broomrape race $\mathrm{F}$ and the subsequent identification and genetic characterization of resistant sources, rapidly overcome again by the parasite, revealed new genetic mechanisms underlying genetic resistance to broomrape not observed in the resistance to previous races, and also some lessons to learn for the future.

First studies on race $\mathrm{F}$ resistance in cultivated germplasm sources (lines P-96 and KI-534) concluded that the trait was controlled by recessive alleles at two loci (Rodríguez-Ojeda et al., 2001; Akhtouch et al., 2002), which clearly differed from the inheritance to previous races. Monogenic, dominant inheritance to race $\mathrm{F}$ was also found in germplasm derived from wild Helianthus spp. (Pérez-Vich et al., 2002), in material developed in Romania (Pâcureanu et al., 2004), and by private companies (unpublished results). However, the results of the evaluation of crosses between some of these resistance sources and different susceptible parental lines showed that dominance relationships were highly dependent on the susceptible parental line used for crossing, as in some cases $F_{1}$ hybrids segregated for resist- 
ance or were susceptible (Pérez-Vich et al., 2004a; Velasco et al., 2006). This suggested that the susceptible lines may affect the expression of the Or genes, producing reversal of the expected dominance, which complicates the practical management of the resistance in breeding programs.

A quantitative trait loci ( $\mathrm{QTL}$ ) analysis on a segregating population derived from the resistant line P-96 (Pérez-Vich et al., 2004b) showed that race F resistance in this line was explained by several QTL with small to moderate effect, mainly associated with the number of broomrape stalks per plant, whereas race E resistance in the same line was mainly explained by a major QTL associated to the resistance or susceptibility character, corresponding to the $\mathrm{Or}_{5}$ gene. These results suggested a major role of a quantitative, non-race specific resistance component affecting the number of broomrape stalks per plant in P-96. Quantitative resistance to race $\mathrm{F}$ has also been reported in the cultivated germplasm lines AM-1, AM-2 and AM-3 (PérezVich et al., 2006a).

The identification of quantitative or horizontal resistance to broomrape opens up new strategies for developing more durable resistance sources, for example combination of vertical and horizontal resistance mechanisms. This will require a preliminary QTL analysis and development of molecular markers linked to major and minor resistance genes to ensure that they are simultaneously introgressed during backcross programs. Additionally, tagging genes modifying dominance of major Or genes is another important research objective. Such studies are being carried out in Spanish breeding programs and they are expected to contribute to providing a more durable and sustainable resistance to sunflower broomrape.

\section{Variability and racial composition of the Spanish sunflower broomrape populations}

In the recent years, sunflower cultivation in Spain and several other countries has been continuously challenged by a rapid evolution of broomrape populations, which have shown strong capacity to spread to new areas and to overcome new resistance mechanisms incorporated into commercial hybrids. Understanding population dynamics in broomrape as well as the genetic bases underlying the virulence of the parasite is becoming crucial for the establishment of effective, long-term breeding strategies. For this purpose, research is being conducted in Spain to determine the genetic diversity and population structure of local broomrape populations. A recent evaluation of the composition of old broomrape populations collected before the use of sunflower hybrids resistant to race $\mathrm{E}$ found out that some populations had a heterogeneous composition, including race $\mathrm{F}$ virulent components (Molinero-Ruiz et al., 2008). This study emphasized that the introduction of hybrids incorporating race $\mathrm{E}$ resistance provided by the $\mathrm{Or}_{5}$ gene produced a selection pressure that promoted an increasing presence of race $\mathrm{F}$ virulent individuals in such populations. 
The ongoing research on broomrape in Spain also covers an in-depth evaluation of the variability and racial composition of the broomrape populations collected on cultivated sunflower at different locations throughout major cultivation areas of Spain over last 20 years, the comparison of local populations with populations from other areas, and also with wild $O$. cumana and local $O$. cernua populations (Pérez-Vich et al., 2006b). The research includes an appropriate comparative analysis with sunflower differential lines and the use of molecular tools. These strategies will contribute to elucidate whether the populations of $O$. cumana parasitizing sunflower in Spain, with wide variation for patogenicity, evolved in situ from a single introduction, or they are the result of a series of seed introductions. Comparison with wild populations and those from several countries will provide information on the possible origin of Spanish populations. Additionally, comparison between $O$. cumana and native $O$. cernua populations will cast light on possible gene flow between them. Knowledge on genetic structure and evolution of $O$. cumana populations will contribute to design more durable and sustainable strategies for sunflower broomrape control. Moreover, the development of molecular tools for identifying and monitoring $O$. cumana races will provide breeders and plant pathologists with more accurate tools for classifying them.

\section{CONCLUDING REMARKS}

Sunflower cultivation in Spain is currently constrained by a reduced cropping season associated to spring plantings, which determines that the crop is subjected to water deficits and an increasing incidence of new virulent races of sunflower broomrape that severely affect seed yield. With this situation, a set of integrated strategies including early planting, use of herbicide-tolerant cultivars to simultaneously control weeds and broomrape, and the development of more durable genetic resistance offers an excellent opportunity to optimize the cropping system and to increase sunflower yield in Spain and other Mediterranean countries. Novel approaches to improved durability of broomrape resistance include the combination of vertical and horizontal resistance mechanisms assisted by the use of molecular markers. Reproducible molecular markers for accurately identifying $O$. cumana races are also being developed. The combination of such strategies is expected to contribute to improved sunflower performance in areas infested by broomrape in the Mediterranean area.

\section{REFERENCES}

Akhtouch, B., Muñoz-Ruz, J., Melero-Vara, J.M., Fernández-Martínez, J.M. and Domínguez, J., 2002. Inheritance of resistance to race F of broomrape (Orobanche cumana Wallr.) in sunflower lines of different origin. Plant Breed. 121: 266-269.

Al-Khatib, K., and Miller, J.F., 2000. Registration of four genetic stocks of sunflower resistant to imidazolinone herbicides. Crop Sci. 40: 869-870. 
Al-Khatib, K., Baumgartner, J.R., Peterson, D.E.and Currie, R.S., 1998. Imazethapyr resistance in common sunflower (Helianthus annuus L.). Weed Sci. 46:403-407.

Alonso, L.C., 2008. Sunflower in Spain: Past and present trends in an international context. In: Velasco, V. [ed.], Proc. $17^{\text {th }}$ Int. Sunflower Conf., Córdoba, Spain, June 8-12, 2008. Int. Sunflower Assoc., Paris. pp. 53-68.

Alonso, L.C., Fernández-Escobar, J., López, G., Rodríguez-Ojeda, M. and Sallago, F., 1996. New highly virulent sunflower broomrape (Orobanche cernua Loefl.) pathotype in Spain. In: Moreno, M., Cubero, J., Berner, D., Joel, D., Musselman, L., and Parker, C. [Eds], Advances in Parasitic Plant Research. Proc. $6^{\text {th }}$ Int. Symp. Parasitic Weeds. Córdoba, Spain, 16-18 April 1996. pp. 639-644.

Alonso, L.C., Rodríguez-Ojeda, M.I., Fernández-Escobar, J. and Lopez-Calero., G., 1998. Chemical control of broomrape (Orobanche cernua Loefl.) in sunflower (Helianthus annuus L.) resistant to imazethapyr herbicide. Helia 21:45-54.

Christov, M., Srindova, P., Entcheva, V., Venkov, V., Nikolova, L., Piskov, A., Petrov, P. and Nikolova, V., 1996. Development of fertility restorer lines originating from interspecific hybrids of genus Helianthus. Helia 19: 65-72.

Domínguez, J., 1996. Estimating effects on yield and other agronomic parameters in sunflower hybrids infested with the new races of sunflower broomrape. In: Proc. Symposium on Disease Tolerance in Sunflower, Beijing, China, International Sunflower Association, Paris. pp. 118-123.

Domínguez, J., 1999. Inheritance of the resistance to Orobanche cumana Wallr. In: Cubero J.I. et al., [Eds.], Resistance to broomrape: The state of the art. Congresos y Jornadas 51/99. Junta de Andalucía. Consejería de Agricultura y Pesca, Seville, Spain. pp. 139-141.

Domínguez, J., Melero-Vara, J.M., Ruso, J., Miller, J. and Fernández-Martínez, J.M., 1996. Screening for resistance to broomrape (Orobanche cernua) in cultivated sunflower. Plant Breed. 115: 201-202.

Eizenberg, H., Plakhine, D., Landa, T., Achdari, T., Joel, D.M. and Hershenhorn, J., 2004. First report of a new race of sunflower broomrape (Orobanche cumana) in Israel. Plant Dis. 88: 1284 .

Fernández-Martínez, J.M., Domínguez, J., Pérez-Vich, B. and Velasco, L., 2008. Update on breeding for resistance to sunflower broomrape. Helia 31(48): 73-84.

Fernández-Martínez, J.M., Melero-Vara, J.M., Muñoz-Ruz, J., Ruso, J. and Domínguez, J., 2000. Selection of wild and cultivated sunflower for resistance to a new broomrape race that overcomes resistance to $\mathrm{Or}_{5}$ gene. Crop Sci. 40: 550-555.

Fernández-Martínez, J.M., Pérez-Vich, B., Akhtouch, B., Velasco, V., Muñoz-Ruz, J., MeleroVara, J.M. and Domínguez, J., 2004. Registration of four sunflower germplasms resistant to race $\mathrm{F}$ of broomrape. Crop Sci. 44: 1033-1034.

Gontcharov, S.V., Antonova, T.S. and Araslanova, N.M., 2004. Sunflower breeding for resistance to the new broomrape race. Helia 27(40): 193-198.

Gulya, T.J., Aydin, A. and Brothers, M., 1994. Evaluation of broomrape (Orobanche cumana) resistance in sunflower germplasm of the USDA Plant Introduction collection. In: Proc. $16^{\text {th }}$ Sunflower Res. Workshop, Fargo, ND, USA, 13-14 January, 1994. Natl. Sunf. Assoc., Bismarck, ND, USA. pp. 53-55.

Ish-Shalom-Gordon, N., Jacobsohn, R. and Cohen, Y., 1993. Inheritance of resistance to Orobanche cumana in sunflower. Phytopathol. 83: 1250-1252.

Jan, C.C. and Fernández-Martínez, J.M., 2002. Interspecific hybridization, gene transfer, and the development of resistance to broomrape race F in Spain. Helia 25(36): 123-136.

Jan, C.C., Fernández-Martínez, J.M., Ruso, J. and Muñoz-Ruz, J., 2002. Registration of four sunflower germplasm populations resistant to broomrape race F. Crop Sci. 42: 22172218.

Kaya, Y., Evci, G., Pekcan, V. and Gucer, T., 2004. Determining new broomrape-infested areas, resistant lines and hybrids in Trakya region of Turkey. Helia 27(40): 211-218.

Melero-Vara, J.M., Dominguez J., and Fernández-Martínez, J.M. 2000. Update on sunflower broomrape situation in Spain: racial status and sunflower breeding for resistance. Helia 23(33): 45-56.

Miller, J.F., and Al-Khatib, K., 2002. Registration of imidazolinone herbicide-resistant sunflower maintainer (HA 425) and fertility restorer (RHA 426 and RHA 427) germplasms. Crop Sci. 42:988-989.

Molinero-Ruiz, M.L. and Melero-Vara, J.M., 2005. Virulence and aggressiveness of sunflower broomrape (Orobanche cumana) populations overcoming the $\mathrm{Or}_{5}$ gene. In: Seiler, G.J., 
[ed.], Proc $16^{\text {th }}$ Int. Sunflower Conf., Fargo, ND, August 29-September 2, 2004. Int. Sunflower Assoc., Paris. pp. 165-169.

Molinero-Ruiz M.L., Pérez-Vich, B., Pineda-Martos, R. and J.M. Melero-Vara, J.M., 2008. Indigenous highly virulent accessions of the sunflower root parasitic weed Orobanche cumana. Weed Res. 48: 169-178.

Pacureanu, M., Veronesi, C., Raranciuc, S. and Stanciu, D., 2004. Parasite-Host plant interaction of Orobanche cumana Wall. (Orobanche cernua Loefl) with Helianthus annuus. In: Seiler, G.J. [Ed.], Proc $16^{\text {th }}$ Int. Sunflower Conf., Fargo, ND, August 29-September 2, 2004. Int. Sunflower Assoc., Paris. pp. 171-177.

Parker, C., 1994. The present state of Orobanche problem. In: Pieterse, A.H., Verkleijand, J.A.C., and Ter Borg, S.J. [Eds.], Biology and management of Orobanche. Proc. $3^{\text {rd }}$ Int. Workshop on Orobanche and Related Striga Research, Royal Tropical Institute, Amsterdam. pp. 17-26.

Pérez-Vich, B., Akhtouch, B., Muñoz-Ruz, J., Fernández-Martínez, J.M. and Jan, C.C., 2002. Inheritance of resistance to a highly virulent race " $F$ " of Orobanche cumana Wallr. in a sunflower line derived from interspecific amphiploids. Helia 25(36): 137-144.

Pérez-Vich, B., Akhtouch, B., Mateos, A., Velasco, V., Jan, C.C., Fernández, J., Domínguez, J. and Fernández-Martínez, J.M., 2004a. Dominance relationships for genes conferring resistance to sunflower broomrape (Orobanche cumana Wallr.). Helia 27(40): 183-192.

Pérez-Vich, B., Akhtouch, B., Knapp, S.J., Leon, A.J., Velasco, V., Fernández-Martínez, J.M. and Berry, S.T., 2004b. Quantitative trait loci for broomrape (Orobanche cumana Wallr.) resistance. Theor. Appl. Genet. 109: 92-102.

Pérez-Vich, B., Velasco, L., Muñoz-Ruz, J., Domínguez, J. and Fernández-Martínez, J.M., 2006a. Registration of three sunflower germplasms with quantitative resistance to race F of broomrape. Crop. Sci. 46: 1406-1407.

Pérez-Vich, B., Molinero-Ruiz, M.L., Melero-Vara, J.M., Pujadas-Salvà, A.J., Stoyanov, K., Fernández-Martínez, J.M., and Velasco, L. 2006b. A multidisciplinary study for determining genetic diversity in Orobanche cumana Wallr. Populations in Spain. Workshop on Parasitic Plant Management in Sustainable Agriculture. COST Action 849, Parasitic Plant Management in Sustainable Agriculture. 23-24 November 2006, Oeiras-Lisbon, Portugal.

Pustovoit, V.S., 1966. Selection, seed culture and some agrotechnical problems in sunflower. Translated from the Russian in 1976 by Indian National Scientific Documentation Centre (INSDOC), Delhi, India.

Rodríguez-Ojeda, M.I., Fernández-Escobar, J. and Alonso, L.C., 2001. Sunflower inbred line (KI-374) carrying two recessive genes for resistance against a highly virulent Spanish population of Orobanche cernua Loefl. / O. cumana Wallr. race " $F "$. In: Proc. $7^{\text {th }}$ Int. Parasitic Weed Symposium, 5-8 June 2001. Nantes, France. pp. 208-211.

Ruso, J., Sukno, S., Domínguez-Giménez, J., Melero-Vara, J.M. and Fernández-Martínez, J.M., 1996. Screening of wild Helianthus species and derived lines for resistance to several populations of Orobanche cernua. Plant Dis. 80: 1165-1169.

Shindrova, P. 2006. Broomrape (Orobanche cumana Wallr.) in Bulgaria - distribution and race composition. Helia 29(44): 111-120.

Škorić, D., 1988. Sunflower breeding. Uljarstvo 25: 1-90.

Sukno, S., Melero-Vara, J.M. and Fernández-Martínez, J.M., 1999. Inheritance of resistance to Orobanche cernua Loefl. in six sunflower lines. Crop Sci. 39: 674-678.

Velasco, L., Pérez-Vich, B., Jan, C.C. and Fernández-Martínez, J.M., 2006. Inheritance of resistance to broomrape (Orobanche cumana Wallr.) race $\mathrm{F}$ in a sunflower line carrying resistance genes from wild sunflower species. Plant Breed. 126: 67-71.

Vrânceanu, A.V., Tudor, V.A., Stoenescu, F.M. and Pirvu, N., 1980. Virulence groups of Orobanche cumana Wallr. differential hosts and resistance sources and genes in sunflower. In: Proc. $9^{\text {th }}$ Int. Sunflower Conf., Torremolinos, Spain, 8-13 July 1980. Int. Sunflower Assoc., Paris. pp. 74-80. 


\title{
ESTADO ACTUAL DE LA INVESTIGACIÓN PARA EL CONTROL DEL JOPO DEL GIRASOL EN ESPAÑA
}

\author{
RESUMEN
}

El jopo de girasol (Orobanche cumana Wallr.) continúa siendo uno de los problemas más importantes de la producción de girasol en España. En los últimos diez años, la resistencia genética ha sido la estrategia predominante para el control de O. cumana. Sin embargo la introducción de nuevos genes de resistencia es frecuentemente seguida por la rápida aparición de nuevas razas virulentas que superan esta resistencia. En esta revisión se discute una estrategia combinada para el control de $O$. cumana que incluye:

a) El uso de cultivares IMI para controlar malas hierbas de primavera e invierno y el jopo de girasol.

b) La combinación de mecanismos resistencia vertical y horizontal en el mismo genotipo, apoyada por marcadores moleculares con el objetivo de desarrollar una resistencia más duradera.

c) El estudio de la variabilidad y composición racial de poblaciones españolas de jopo utilizando métodos clásicos y moleculares con el objetivo de obtener información sobre dinámica de poblaciones en este planta parásita.

La combinación de estas estrategias se espera que contribuya a mejorar el comportamiento del girasol en zonas infectadas por el jopo en el área Mediterránea.

\section{STRATÉGIES DE RECHERCHE EN COURS POUR CONTRÔLER I'Orobanche DU TOURNESOL EN ESPAGNE}

\author{
RÉSUMÉ
}

L'Orobanche du tournesol (Orobanche cumana Wallr) continue d'être l'un des problèmes les plus importants dans la production de tournesol en Espagne. Ces dix dernières années, la résistance génétique a été la stratégie prédominante de contrôle contre $O$. cumana.

Cependant, l'introduction de nouveaux gènes de résistance est fréquemment suivie par l'apparition de nouvelles races virulentes les contournant. Dans ce rapport, une stratégie combinée de contrôle d'O. cumana est discutée, incluant:

a) L'utilisation des cultivars de tournesol IMI (résistants aux Imidazoles) pour contrôler les adventices d'hiver et de printemps ainsi que l'Orobanche.

b) L'utilisation conjointe de mécanismes de résistances verticaux et horizontaux dans le même génotype, assistée par les marqueurs moléculaires afin de développer une résistance plus durable.

c) L'étude de la variabilité et de la composition des souches des populations espagnoles d'Orobanche du tournesol, en utilisant des approches classiques et moléculaires dans le but d'apprendre la dynamique de populations de ce parasite.

La combinaison de telles stratégies est attendue pour contribuer à améliorer les performances du tournesol dans les zones infestées par l'Orobanche en région méditerranéenne. 
